\title{
Global Strategy and Emerging Markets
}

Alvaro Cuervo-Cazurra, Northeastern University, USA

Joseph Ganitsky, University of Miami, USA

Yadong Luo, University of Miami, USA

John Mezias, University of Miami, USA

\section{Introduction}

The last two decades have witnessed an increase in interest in understanding the global expansion of emerging market multinationals (EMNCs). We propose that the uniqueness in studying EMNCs is how their home country environments impact their behavior. Specifically, we argue that their underdeveloped economies, which are undergoing pro-market reforms, and their underdeveloped pro-market institutions both affect ownership, capability, and innovation of firms, which in turn drive their internationalization and global success. Thus, this framework links the underdevelopment of emerging markets to firm internationalization via firms' characteristics and strategies. The framework was derived from presentations and conversations at the Global Strategy and Emerging Markets Conference that took place at the University of Miami in January 6-8, 2016. This issue's Editorial Commentary provides more information about this conference.

\section{Global Strategy and Emerging Markets : A Frame- work}

The rise of EMNCs has led to an increasing interest in these firms. These firms are now part of the competitive landscape, with multinationals from advanced economies encountering EMNCs in both emerging economies and advanced countries. Although EMNCs entered the competitive landscape several decades ago, scholarly interest in these firms is relatively recent. An incipient literature in the 1980s identified the phenomenon (e.g., Wells, 1983), but deep interest in analyzing these firms did not emerge until the late 2000s (e.g., Khanna \& Palepu, 2006; Luo \& Tung, 2007).

The plethora of studies analyzing these firms yield not only new insights on their behavior and distinct patterns of internationalization (e.g. Luo \& Tung, 2007) but also new insights on the theory of the multinational enterprise (Cuervo-Cazurra, 2012). These new insights emerge from the study of these firms and, more importantly, from identifying key features that make their study distinct.

From conference sessions and discussions we derived a framework that helped organize the various conference papers and establish links among them, and so offer guidance for future research on EMNCs. Figure 1 illustrates our framework. We first identified two characteristics of emerging markets that seem to drive strategies of EMNCs: economic underdevelopment and pro-market transformation, and the underdeveloped pro-market institutions. These two defining characteristics of emerging markets appear to influence three key dimensions of EMNCs' behavior: ownership, capabilities, and innovation. Through their influence on ownership, capabilities, and innovation, these environmental characteristics explain much of the differential behavior of EMNCs in terms of their internationalization, and their ultimate global success. This framework is not meant to be a comprehensive analysis of all research on EMNCs, since there is already research analyzing the influence of home country on international expansion of EMNCs (e.g., Luo \&Wang, 2012). Rather, it summarizes insights gained from the confer-

Figure 1. Emerging Markets and the Behavior of Emerging Market Multinationals

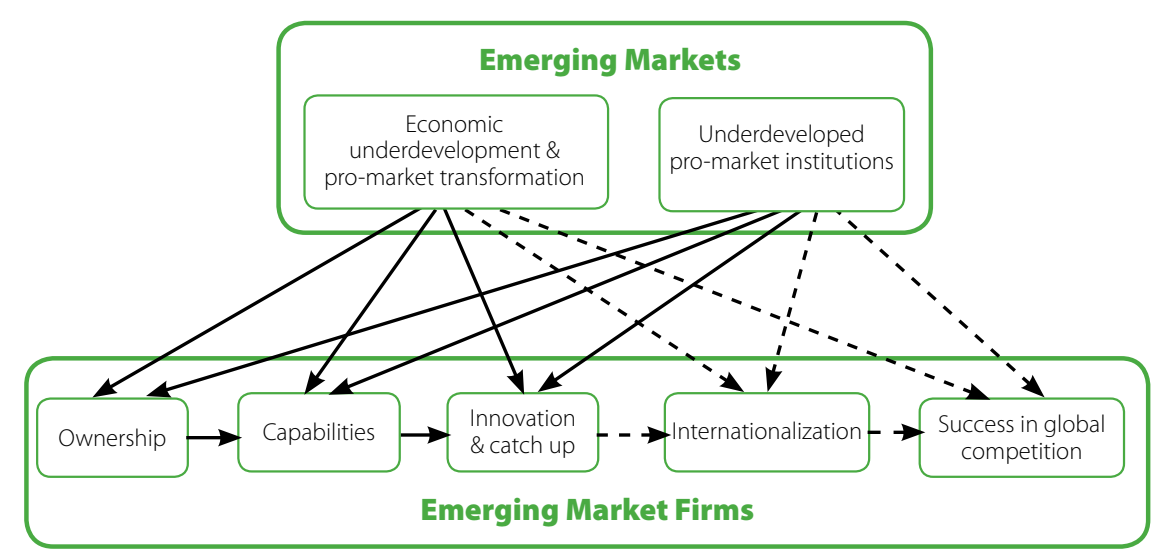

Note: Solid arrows illustrate commonly analyzed relationships, while dashed arrows illustrate less known relationships. 
ence that help classify and organize future research. In Figure 1 we also highlight with dashed arrows the relationships that are still understudied, warranting much greater attention in future research.

\section{Characteristics of Emerging Markets}

\section{Economic Underdevelopment and Underdeveloped Pro-Market Institutions}

Countries that have relative economic underdevelopment but are undergoing pro-market reforms, and that have relatively underdeveloped institutions are usually considered emerging economies (Hoskisson et al., 2000). For a more detailed discussion of how to define emerging markets, please see the Ghemawat and Altman article in this issue.

Economic underdevelopment is important for understanding how emerging market firms behave. Emerging economies may not have large segments of the population with high income levels capable of paying premium prices for products, highly sophisticated providers of inputs or supporting services, or advanced transportation and communication infrastructure. As a result, many EMNCs have to invest in domestic infrastructure to compensate for deficiencies in the provision of assets by their governments. Nevertheless, nascent pro-market reforms have altered the competitive landscape and led these firms to improve competitiveness.

Underdeveloped pro-market institutions is the second dimension that tends to characterize emerging markets. Underdeveloped pro-market institutions have been called institutional voids (Khanna \& Palepu, 2010). We believe that emerging markets may not lack institutions, but rather have weak or underdeveloped pro-market institutions. Many studies analyzing EMNCs have focused on this dimension of the environment, investigating how weak institutions encourage EMNCs to undertake investments and upgrade capabilities.

\section{Ownership, Capabilities, and Innovation}

We identified three sets of characteristics of EMNCs that seem to drive their behavior as a result of their country of origin: ownership, capabilities, and innovation. Although these dimensions have interrelations in defining global strategy, discussed later, for now we organize these in a sequential process to better understand influences of home country characteristics on them.

First, ownership of emerging market firms appears to be influenced by the underdevelopment of the country and, especially, of financial institutions that ensure access to abundant and low cost capital and protect investors' rights. As a result, state-owned firms seem to take a particular preeminence in emerging markets, with the state becoming an investor that provides firms with the capital required to offer needed products and services. This is not only the case of utilities, in which the state has been a usual investor, but also of sectors requiring large amounts of capital which private investors may not be able to obtain in emerging markets, such as in heavy industries. The lack of investor protection may also result in the emergence of large family-owned firms that substitute for capital markets and become business groups. These family-owned firms achieve control of the ever-expanding set of firms via pyramidal ownership (gaining control of a firm via a chain of ownership relations) thus, becoming primary investors in other firms. This pyramidal investment pattern often reaches a point in which even though the family has a small stake in a firm, it exercises control.

Second, capabilities of EMNCs depend in part on a country's supporting infrastructure and comparative advantages, such as education and innovation systems. Firm capabilities depend not only on a firm's investments, but also on the quality of inputs it obtains. In many emerging markets available inputs tend to be of lower quality and sophistication, especially inputs that must be developed rather than those that are part of the country's endowment. This shortcoming is due to three primary reasons: (1) Individuals, private and public sectors are unable to invest sufficiently in developing an educated workforce, which limits the pool of skilled employees needed to improve firm competitiveness. (2) The government has not developed a clear regulatory framework, which would have enabled firms to invest in capabilities without fear of expropriation. (3) Weaknesses in infrastructure also make input providers less sophisticated and unable to provide quality intermediate inputs to firms because they lack specialization. Thus, EMNCs cannot rely on external providers for many inputs, even if these inputs or services have little to do with the overall ability of firms to compete in global markets (e.g., security, cleaning services or transportation). Instead EMNCs often have to internalize activities done by specialists in advanced economies, thus becoming much more vertically integrated and diversified. As a result of these limitations, EMNCs must develop and leverage a wide array of capabilities instead of focusing on their core areas or activities.

Third, EMNCs suffer from the weakness of innovation systems in emerging markets, which limit their ability to develop highly sophisticated technology and innovate. Notwithstanding some exceptional technological leaders, many EMNCs tend to have less sophisticated technologies than competitors in advanced economies. For a more detailed discussion of technology gaps, please see the Song article in this issue. The main reason for this is that innovation systems in emerging markets are less developed due to lower previous public and private investments in $R \& D$, a less sophisticated university educational infrastructure yielding less creative and inquisitive professionals, lower or no tax incentives for R\&D investments, as well as less protection of intellectual property rights. These factors discourage firms from investing in technology. Thus, EMNCs appear to follow different paths for developing technology and innovating (Luo \& Tung, 2007). Some firms copy ideas and innovations from advanced market multinationals via reverse engineering in an attempt to improve competitiveness without having to invest in innovation. Other firms focus on process and business models innovations, because these are more difficult to copy than product innovations. Some firms improve technology by establishing alliances or becoming part of the global supply chain of advanced economy multinationals 
and integrating advanced market multinationals' more sophisticated process technologies. Yet other firms focus on creating product and/ or business models innovations that reduce production and operation costs and address limitations to distribution and customer payments, which are more appropriate for emerging markets.

\section{Innovation and Escape Internationalization}

These three firm-level characteristics-ownership, capabilities, and innovation-influence ways in which EMNCs internationalize. We consider two different ways (Cuervo-Cazurra \& Ramamurti, 2014): internationalization in other countries to take advantage of innovations and capabilities developed in the home country, and internationalization to solve some limitations of the home country.

First, internationalization to take advantage of innovations created in the home country reflects the usual argument that ownership advantages help firms expand abroad, but for EMNCs, ownership advantages that have internationalized take additional dimensions that help these firms achieve success in global competition. One dimension is developing innovations for the base of the pyramid, that is, individuals in the lower segments of income. EMNCs create products and services to serve poor consumers in their home countries and use these innovations to serve poor consumers in other emerging economies. These innovations can also become the so-called reverse innovations (Govindarajan \& Ramamurti, 2011), in which innovations that are created for individuals at the base of the pyramid in emerging countries are transferred to advanced economies to serve the needs of higher income individuals there. EMNCs can also use expertise gained in dealing with weak institutions at home to achieve an advantage and become leading investors in other countries with weak institutions (Cuervo-Cazurra \& Genc, 2008). Thus, managers develop an ability to deal with underdeveloped pro-market institutions in the home country in the form of a flexible management style and better management of uncertainty in rules and regulations that provides their firms with an advantage when they enter other emerging markets with weak institutions.

Second, internationalization often helps EMNCs avoid underdeveloped conditions of their home countries. This is an extension of the institutional escape argument (Witt \& Lewin, 2007) but EMNCs can escape both the uncertainty and high risks in emerging markets, and the harsh conditions that their governments may impose; and seek more stable and predictable institutional settings in which EMNCs may experience greater success. Thus, EMNCs escape poor institutions of the home country in search of foreign financial markets that provide better protection of shareholder rights. They also escape poor technological conditions in their home country that discourage developing advanced technology. Some EMNCs achieve this by purchasing technologically sophisticated firms in advanced economies, which facilitates access to better innovation systems and transfer of advanced tacit technologies.

\section{Conclusions}

The framework presented here has important implications for international business research. It provides an overarching explanation of the mechanisms that link the conditions that characterize emerging markets to the international expansion of their firms. We go beyond a summary of existing arguments and provide a complete framework that connects the underdevelopment of the economy and institutions of emerging markets to their competitive behavior and internationalization. These areas have received limited attention in the literature. Thus, with this framework we encourage studies that not only provide additional depth to the analysis of the relationship between ownership, capabilities, innovation and internationalization, but also studies that analyze these relationships within the economic and institutional context in which firms operate. Future studies can analyze areas that have received little attention, for example the influence of economic and institutional development on internationalization and success, or the interaction between innovation and internationalization, and the impact of internationalization on success. Future studies can also analyze how particular characteristics of emerging markets might have an impact in ways not predicted by traditional models of the multinational. These traditional models were developed with the implicit assumption of an advanced economy that provides companies with soft and hard infrastructures that are supportive. However, such infrastructures are not as well developed in emerging economies and thus the mechanisms and predictions of existing models likely need modification. In this sense, studies of EMNCs have potential to extend existing models of the multinational. But to do this any study of EMNCs must account for the context of their behavior and how being in an emerging country affects their ownership, capabilities, innovation an internationalization. It is the influence of this context that holds promise for such analyses of EMNCs to extend and transform existing models of the multinational enterprise. We hope this framework will spur additional research to broaden our understanding of EMNCs and their potential for advancing the theory of the multinational enterprise.

\section{References}

Cuervo-Cazurra, A. 2012. How the analysis of developing country multinational companies helps advance theory: Solving the Goldilocks debate. Global Strategy Journal, 2: 153-167.

Cuervo-Cazurra, A., \& Genc, M. 2008. Transforming disadvantages into advantages: Developing country MNEs in the least developed countries. Journal of International Business Studies, 39: 957-979.

Cuervo-Cazurra, A., \& Ramamurti, R. 2014. Conclusion: An agenda for EMNC research. In A. Cuervo-Cazurra \& R. Ramamurti (Eds), Understanding Multinationals from Emerging Markets: 271-299. Cambridge: Cambridge University Press.

Govindarajan, V., \& Ramamurti, R. 2011. Reverse innovation, emerging markets and global strategy. Global Strategy Journal, 1: 191-205. 
Hoskisson, R. E., Eden, L., Lau, C. M., \&Wright, M. 2000. Strategy in emerging economies. Academy of Management Journal, 43: 249-267.

Khanna, T., \& Palepu, K. G. 2006. Emerging giants: Building world-class companies in developing countries. Harvard Business Review, October: 60-69.

Khanna, T., \& Palepu, K. G. 2010. Winning in emerging markets: A road map for strategy and execution. Boston, MA: Harvard Business Press.

Luo, Y., \& Tung, R. L. 2007. International expansion of emerging market enterprises: A springboard perspective. Journal of International Business Studies, 38: 481-498.

Luo, Y., \&Wang, S. L. 2012. Foreign direct investment strategies by developing country multinationals: A diagnostic model for home country effects. Global Strategy Journal, 2: 244-261.

Wells, L. T. 1983. Third world multinationals. Cambridge, MA: MIT Press.

Witt, M. A., \& Lewin, A. Y. 2007. Outward foreign direct investment as escape response to home country institutional constraints. Journal of International Business Studies, 38: 579-594.

Alvaro Cuervo-Cazurra (a.cuervocazurra@neu.edu) is Professor of International Business and Strategy at Northeastern University, AIB Fellow and co-editor of Global Strategy Journal. He studies the internationalization of firms, particularly emerging market multinationals; capability upgrading, focusing on technological capabilities; and governance issues, especially corruption in international business. He received a Ph.D. from MIT.

Joseph Ganitsky (jganitsky@miami.edu) received his DBA from Harvard University, and is Director of the University of Miami's CIBER. He specializes in Global Entrepreneurship and Strategy, has taught at INCAE, Managua; Universidad de Los Andes, Bogota; Jerusalem Institute of Management, Tel Aviv; and Tulane and Loyola Universities, New Orleans; and held visiting appointments at Instituto de Empresa, Madrid; and IESA, Caracas. He has also served in different capacities AIB, BALAS and CLADEA.

Yadong Luo (yadong@miami.edu) is Emery Findley Distinguished Chair and Professor of Management at the University of Miami. His research interests include global strategy, cooperative alliances, and business and management in emerging markets.

John M. Mezias (jmezias@miami.edu) is an Associate Professor at the University of Miami's School of Business Administration. He studies international human resource management, adaptation strategies of multinational corporations, and legal consequences of strategic actions. He received his PhD from New York University's Stern School of Business. 